\title{
PRO DAN KONTRA PANDANGAN PEGAWAI PENCATAT NIKAH (PPN) ATAS PERUBAHAN BATASAN USIA MINIMAL PERKAWINAN DALAM UNDANG-UNDANG NOMOR 16 TAHUN 2019
}

\author{
Thiyas Tono Taufiq \\ Universitas Islam Negeri Walisongo Semarang \\ thiyastono92@walisongo.ac.id \\ Qotrunnada Zulfa Hafsari \\ Alumni Prodi Hukum Keluarga Islam \\ Universitas Islam Negeri Sunan Kalijaga Yogyakarta \\ nadazulfa19@gmail.com
}

\begin{abstract}
This research focuses on discussing changes in the minimum age for marriage as stipulated in Law Number 16 of 2019 as an amendment to Law Number 1 of 1974 concerning marriage. The new Marriage Law changes the minimum marriage limit for men and women who will marry at least 19 years of age, previously the marriage limit for men is 19 years old and for women is 16 years old. This research seeks to find the pros and cons of legalizing the minimum age limit for marriage according to the views of the staff of the marriage register at the Office of Religious Affairs (KUA) in Yogyakarta who were non-randomly selected. The results of this research indicate that the process of changing the age limit of marriage does not see the pros and cons in society. Most importantly, the enactment of this law can hurt women, so that the purpose of reforming Islamic family law can realize legal unification by the times.
\end{abstract}

Keywords: Marriage, Law, Age Limit, Legal Unification

\section{PENDAHULUAN}

Lahir dan disahkannya Undang-Undang Nomor 16 Tahun 2019 merupakan respon positif pemerintah Indonesia yang menilai bahwa batasan usia perkawinan layak untuk dinaikan usianya. Pemerintah dalam hal ini sangat serius untuk membuat undang-undang baru yang menggantikan undang-undang lama. Jika ditelaah lebih jauh, lahirnya sebuah undang-undang tidak terlepas dari historisitas perumusan undang-undang, dinamika sosial, dan konfigurasi politik yang merupakan faktor lahirnya undang-undang tersebut.

Alasan mengenai perubahan batasan usia minimal perkawinan, menurut pernyataan Tubagus Haryo Karbyanto sebagai kuasa hukum pemohon dalam sidang pemeriksaan pendahuluan yang diketuai oleh Ahmad Fadlil Sumadi di ruang sidang Mahkamah Konstitusi (MK), dapat disimpulkan bahwa praktik perkawinan pada anak yang masih di bawah umur bisa menyebabkan dirampasnya hak anak untuk tumbuh, berkembang, serta memperoleh pendidikan secara maksimal. Pasal inilah yang dianggap merugikan pihak perempuan. Selain itu, pasal tersebut dianggap adanya ketidakadilan dalam memberikan hak antara anak perempuan dengan 
anak laki-laki. Hal ini tentu memunculkan ketimpangan dan ketidakadilan hukum yang seharusnya tidak boleh terjadi. ${ }^{1}$

Mengenai alasan perubahan undang-undang baru di atas masih mengalami perdebatan di masyarakat antara yang sepakat dan tidak sepakat terhadap adanya undang-undang baru tersebut. Di satu sisi ada pihak yang sepakat atas perubahan usia minimal kawin yang setara usianya antara laki-laki maupun perempuan, yakni berusia 19 (sembilan belas) tahun. Namun di sisi lain juga ada pihak yang tidak sepakat dengan putusan lahir dan disahkannya UndangUndang (UU) Perkawinan Nomor 16 tahun 2019. Menurut Yohana Yembise, selaku Menteri Perlindungan Perempuan dan Pemberdayaan Anak, batasan usia minimal perkawinan dapat dinilai dari kedewasaan baik secara jiwa maupun raga agar dapat melangsungkan perkawinan secara matang serta mendapatkan keturunan yang berkualitas. ${ }^{2}$

Adapun menurut Ratno Lukito, ada beberapa penyebab dari peristiwa (perubahan standar usia perkawinan), yakni sebagai berikut: Pertama, belum rampungnya telaah teoritis tentang usia dewasa dalam praktik perkawinan. Kedua, dalam mempraktikkan perkawinan, masyarakat cenderung memiliki pemahaman fiqih klasik serta budaya masyarakat setempat atau daerah tertentu. Ketiga, negara kesulitan mengaplikasikan batasan usia minimal perkawinan yang sesuai dengan tujuan dari Rancangan Undang-Undang (RUU) Perkawinan, hal ini terkait relasi gender tradisionalis. Bahwasannya problem penentuan batasan usia minimal perkawinan lebih condong mengenai perdebatan antara hukum negara dengan tradisi dalam agama (Islam). ${ }^{3}$

Batasan usia minimal perkawinan adalah salah satu cita-cita pemerintah untuk mengurangi persoalan perkawinan, salah satunya adalah perkawinan usia dini. Bahwasannya perkawinan dini merupakan praktik tradisional yang telah lama dikenal dan tersebar luas di berbagai penjuru dunia. ${ }^{4}$ Selain itu, menurut Mark E. Cammack dengan adanya unifikasi hukum perkawinan diharapkan mampu memenuhi tuntutan era modernisasi yang telah ada pada

\footnotetext{
${ }^{1}$ Lihat Agus Sahbani, 2014. https://m.hukumonline.com/berita/baca/lt533d336b345e4/batas-usia-pernikahandigugat, diakses pada 14 Desember 2019.

${ }^{2}$ Maulana Kautsar, "UU Perkawinan Diteken, Usia Minimal Menikah 19 Tahun," 2019, www.dream.co.id/news/uu-perkawinan-diteken-batas-minimal-menikah-19-tahun-1910249.html, diakses pada 19 Desember 2019.

${ }^{3}$ Ratno Lukito. 2008. Hukum Sakral dan Sekuler: Studi Tentang Konflik dan Resolusi Konflik dalam Sistem Hukum di Indonesia. (Jakarta: Alvabeta). h. 270.

${ }^{4}$ Djamilah dan Reni Kartikawati. 2014. "Dampak Perkawinan Anak di Indonesia" Jurnal Studi Pemuda, 3 (1), h. 3.
} 
negara-negara lain, serta diharapkan mampu mewujudkan program persatuan Indonesia yang bernafaskan Pancasila. ${ }^{5}$

Masyarakat Indonesia yang beragam yang menganut berbagai macam golongan, madzhab, adat, kepercayaan, dan agama yang berbeda, maka perlu usaha unifikasi hukum. Tujuan adalah agar penyatuan hukum bisa menjadi satu hukum yang berlaku bagi seluruh elemen masyarakat, yang bisa mencakup wilayah negara dan menjadi bagian dari sistem hukum nasional. Oleh sebab itu, alasan adanya pembaharuan hukum Islam merupakan sebuah bentuk unifikasi dikarenakan adanya sejumlah madzhab, golongan, adat, kepercayaan dan agama yang dianut oleh negara yang bersangkutan. ${ }^{6}$

Setelah disahkannya Undang-Undang Nomor 16 Tahun 2019 yang telah banyak dipersoalkan dan menuai perdebatkan, terutama ketika merujuk pendapat para Pegawai Pencatat Nikah selanjutnya singkat PPN pada Kantor Urusan Agama (KUA) di wilayah Kota Yogyakarta. Hasil temuan penelitian ini bahwa tuntutan revisi undang-undang mengenai batasan usia kawin setidaknya ada beberapa hal penting. Pertama, dihapuskanya isu diskriminatif; Kedua, pencegahan perkawinan usia dini; Ketiga, mendewasakan usia perkawinan. Dari ketiga hal tersebut, lahirnya undang-undang baru bisa mengakomodir tuntutan isu diskriminatif, yaitu disamakannya usia perkawinan menjadi 19 (sembilan belas) tahun baik bagi laki-laki maupun perempuan.

Adapun pandangan para Pegawai Pencatatan Nikah (PPN) di wilayah Kota Yogyakarta dapat ditarik kesimpulan mengenai dinaikannya batasan usia perkawinan belum sepenuhnya menjawab persoalan perkawinan, hal ini dikarenakan usia belum tentu bisa menjamin kematangan dan kedewasaan seseorang. Selain itu, unifikasi hukum tentang perkawinan juga penting untuk diimplementasikan sebagai bentuk penyatuan hukum yang beraneka ragama di sertiap daerah di Indonesia, sehingga antara produk hukum adat, hukum Islam maupun hukum Negara bisa diberlakukan sebagai hukum nasional yang berkeadilan.

\section{METODE PENELITIAN}

Untuk memperoleh data kajian yang mendalam, penulis menggali data dengan cara observasi, wawancara, dokumentasi dan data-data pendukung yang relevan. Data penelitian ini

\footnotetext{
${ }^{5}$ Mark E. Cammark. 1993. "Hukum Islam dan Politik Orde Baru," dalam Sudirman Tebba (ed.), Perkembangan Mutakhir Hukum Islam di Asia Tenggara: Studi Kasus Hukum Keluarga dan Pengkodifikasiannya (Bandung: Mizan). h. 27.

${ }^{6}$ M. Nur Hasan Latief. 2016. "Pembaharuan Hukum Keluarga Serta Dampaknya terhadap Pembatasan Usia Minimal Kawin dan Peningkatan Status Wanita,” Jurnal Hukum Novelty, 7 (2): 199.
} 
diperoleh dari para Pegawai Pencatat Nikah (PPN) Kantor Urusan Agama (KUA) di Kota Yogyakarta yang dipilih secara non random sampling, yakni cara pengambilan sampel yang tidak semua populasi diberikan kesempatan untuk dipilih menjadi sampel, agar mendapatkan hasil yang objektif. Maka dalam pengambilan data memilih beberapa KUA di antaranya: KUA Mergangsan, KUA Pakualaman, KUA Tegalrejo, KUA Jetis, KUA Gondokusuman, dan KUA Kotagede. Adapun fokus utama dari penelitian ini yaknik mengenai pembaharuan hukum keluarga Islam, sejarah perubahan batasan usia kawin, terkait dengan batasan usia minimal kawin yang tertuang dalam Undang-Undang Nomor 16 Tahun 2019.

Dalam penelitian ini menggunakan pendekatan antropologi hukum, yang meliputi hukum Islam, hukum adat dan hukum positif. Penggunaan pendekatan antropologi hukum dapat menjadi pisau analisis dalam penelitian hukum Islam. Penelitian hukum Islam dengan pendekatan antroplogi huum dapat dilakukan dengan mengintegrasikan teori-teori dalam ushul fiqih, sosial, sejarah, maupun sosiologi. Dengan demikian pendekatan atropologi hukum akan ditemukan dasar filosofi hukum Islam dan mekanisme pengabdatasiannya pada masa kini.

Agar mendapatkan kesimpulan yang valid dan berkualitas, maka perlu dilakukan analisis secara mendalam. Data yang diperoleh dianalisis menggunakan metode induktif, yakni kerangka berfikir dengan menganalisis fakta dan data secara konkrit, kemudian dirumuskan menjadi generalasi atau kesimpulan. Dalam kajian ini mempunyai tujuan untuk pengembangan keilmuan dalam bidang hukum keluarga Islam secara sistematis dan memperoleh kesimpulan mengenai sejarah, fakta atas perubahan batasan usia minimal perkawinan dari masa ke masa. Selain itu, kajian ini mengungkap pro dan kontra atas disahkannya batasan minimal kawin dalam Undang-Undang (UU) Nomor 16 Tahun 2019 menurut pandangan serta pendapat pegawai pencatat nikah (PPN) pada Kantor Urusan Agama (KUA) di wilayah Kota Yogyakarta.

\section{PEMBAHASAN}

\section{Ketentuan Batas Usia Kawin Menurut Fiqih}

Kata nikah dalam bahasa Arab berasal dari kata al-jam'u yang artinya kumpul. ${ }^{7}$ Kata nikah dapat diartikan "aqdu al-tajwij” yang berarti akad nikah. Menurut pendapat Rahmad Hakim bahwa kata nikah berasal dari Arab yakni nikahun yang merupakan bentuk masdar atau berarti berasal dari kata kerja nakahan yang sinonimnya "tazawwaja", mempunyai arti

\footnotetext{
${ }^{7}$ Sulaiman Al-Mufarraj. 2003. Bekal Pernikahan; Hukum, Tradisi, Hikmah, Kisah, Sya'ir, Wasiat, Kata Mutiara, terj. Kuais Mandiri Cipta Persada. (Jakarta: Qisthi Press). h. 5.
} 
perkawinan. ${ }^{8}$ Di dalam bab I Pasal 1 Undang-Undang (UU) Nomor 1 Tahun 1974 “perkawinan merupakan ikatan lahir dan batin di antara seorang laki-laki dengan perempuan sebagai pasangan suami dan istri yang bertujuan membentuk keluarga yang sakinah, mawaddah, warahmah."

Menurut imam Ath-Thabary sebagaimana yang dikutip oleh Nirwan Nazarudin, sakinah, mawaddah, warahmah merupakan karunia dari Allah untuk manusia pertama, yakni Nabi Adam as dan Siti Hawwa', ketika dinobatkan sebagai pasangan suami dan istri yang sah. Keluarga yang sakinah, mawadaah, warahmah merupakan dambaan bagi setiap pasangan dari latar belakang apapun. ${ }^{9}$

Pembahasan mengenai pernikahan setidaknya ada 23 ayat yang disebutkan di dalam alQur'an. Perihal usia pernikahan tidak satu satu pun yang menjelaskan secara gambling mengenai pembatasan usia minimal ketika hendak melasungkan pernikaham. Namun apabila ditinjau lebih jauh, terdapat beberapa ayat-ayat al-Qur'an yang membahas kelayakan dalam melaksanakan pernikahan di antaranya diterangakan dalam QS. An-Nur ayat 32:

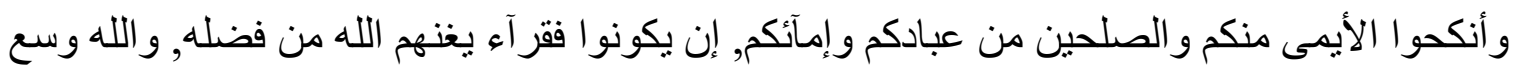

Artinya: "Dan nikahlah orang-orang yang masih membujang di antara kamu, dan juga orang-orang yang layak (menikah) dari hamba-hamba sahayamu yang laki-laki dan perempuan. Jika mereka miskin, Allah akan memberi kemampuan kepada mereka dengan karunia-Nya. Dan Allah Mahaluas (pemberian-Nya), Maha Mengetahui."

Jika ditinjau menurut Tafsir Ibnu Katsir, ayat di atas merupakan salah satu perintah untuk mensegerakan menikah sebagaimana pendapat dari sebagian ulama, yakni mewajibkan nikah bagi mereka yang telah mampu, baik secara lahir maupun batin. ${ }^{11}$ Sementara menurtut Al-Maraghy yang menafsirkan surat an-Nur ayat 32, sebagaimana yang dikutip oleh Mustofa, bahwa kalimat "washalihin", bagi perempuan maupun laki-laki yang telah mampu untuk menikah baik secara jasmani, rohani, sosial serta ekonomi. Adapun menurut pendapat Quraish Shihab, beliau menafsirkan kata "washalihin”, yakni bagi seseorang yang sudah mampu secara mental, spiritual untuk membangun rumah tangga, maka fungsi pernikahan memerlukan

\footnotetext{
${ }^{8}$ Rahmat Hakim, 2000. Hukum Perkawinan Islam. (Bandung: Pustaka Setia). h.11.

${ }^{9}$ Nirwan Nazaruddin. 2020. "Sakinah, Mawaddah, Wa Rahmah sebagai Tujuan Pernikahan: Tinjauan Dalil dan Perbandingannya dengan Tujuan Lainnya Berdasarkan Hadits Shahih,” Jurnal Asy-Syukriyyah, 21 (2). h. 169. ${ }^{10}$ QS. An-Nur (24): 32.

${ }^{11}$ Abi Fada' al-Hafidz Ibnu Katsir. 2014. Tafsir Ibnur Katsir. (Beirut: Dar al-Kutub al-Ilmiyyah). h. 269.
} 
persiapan bukan hanya materi saja, tetapi juga mempersiapkan dari aspek mental dan spiritual bagi calon kedua mempelai. ${ }^{12}$

Allah SWT telah berfirman dalam al-Qur'an surat An-Nisa' ayat 6:

$$
\text { و ابتلو ا اليتمى حتى إذا بلغو ا النكاح فإن أنستم منهم رشدا فادفعوا إليهم أمولهم.. }
$$

Artinya: "Dan ujilah anak-anak yatim itu sampai mereka cukup umur untuk menikah. Kemudian jika menurut pendapatmu mereka telah cerdas (pandai memelihata harta), maka serahkanlah kepada mereka hartanya."

Ayat di atas menegaskan bahwa seorang yang hendak melasungkan pernikahan dianjurkan cukup umur atau dalam bahasa telah berusia baligh, sebab seseorang yang telah baligh dianggap mampu untuk membangun rumah tangga. ${ }^{13}$ Seseorang yang telah baligh apabila seorang laki-laki yang pernah mengalami mimpi, sebagaimana telah disepakati oleh para ulama, bahwa anak yang pernah mimpi lantas ia keluar air mani (sperma) secara tidak sengaja (junub), maka dia dianggap sudah baligh. Lantas ciri-ciri bagi soerang perempuan dianggap sudah baligh ketika sudah mengalami menstruasi (haidh). ${ }^{14}$

Berdasarkan penafsiran ayat di atas, kematangan seseorang bisa dintujukkan melalui mimpi lantas keluar air mani (sperma). Hal ini diperkuat dalam penjabaran dalam kitab "alFiqh 'Ala Madzahib al-Arba'ah', bahwa batas baligh seorang anak biasanya ditandai dengan usia. Menurut pendapat Imam Hanafi ditandai dengan mimpi "basah" bagi seorang laki-laki dan haidh bagi seorang perempuan. Namun jika keduanya tidak ada tanda-tanda khusus, maka usia bisa menjadi tanda baligh, yakni usia 17 (tujuh belas) tahun bagi perempuan dan 18 (delapan belas) tahun bagi perempuan. ${ }^{15}$

Sementara Imam Malik berpendapat, bahwa seorang yang telah baligh ditandai dengan junub dalam kondisi tidur dan secara mutlak atau menghayal. Selain itu, bisa juga ditandai dengan tumbuhnya rambut di anggota tubuh pada area tertentu. Sedangkan menurut pendapat Imam Syafi'i, batasan baligh yakni seseorang yang berusia 15 (lima belas) tahun bagi laki-laki dan 9 (sembilan) tahun bagi laki-laki. Sedangkan menurut pendapat Imam Hambali seorang

\footnotetext{
${ }^{12}$ Mustofa. 2009. Perbandingan Hukum Perkawinan di Dunia Islam. (Bandung: Pustaka al-Fikris). h. 22.

${ }^{13}$ Holilurrohman. 2016. "Batas Usia Ideal Pernikahan Perspektif Maqasid Syariah," Journal of Islamic Studies and Humanities, 1 (1): h. 92.

${ }^{14}$ Muhammad Ali-Al-Shabuny. 1999. Tafsir Ayat al-Ahkam min al-Qur'an (Beirut: Dar al-Kutub al-Ilmiyyah). h. 153.

${ }^{15}$ Achmad Asrori. 2015. "Batas Usia Perkawinan Menurut Fukaha dan Penerapannya dalam Undang-Undang Perkawinan di Dunia Islam,” Jurnal al-Adalah. 12 (4): h. 810.
} 
laki-laki ditandai usia 15 tahun dan telah mimpi "basah", sedangkan perempuan ditandai dengan datang bulan (haidh). ${ }^{16}$

Kedewasaan pada dasarnya dapat ditentukan dengan usia dan juga pada tanda-tanda, sebagaimana hadits yang diriwayatkan oleh Aisyah ra. yang berbunyi:

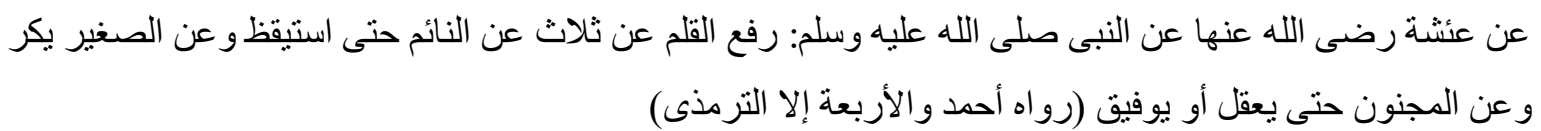

Artinya: "Dari Asiyah ra. Dari Nabi SAW., bersabda: terangkat qalam (pertanggungjawaban) dari tiga hal: orang yang tidur hingga ia terbangun, dari anak kecil hingga ia mimpi, dari orang gila hingga ia siuman (sembuh), dan sadar." (HR. Ahmad dan Imam Empat kecuali Tirmidzi)

Berdasarkan hadits di atas, ciri utama baligh adalah adanya tanda-tanda seperti mimpi (basah) bagi laki-laki dan haidh bagi perempuan. Hadits tersebut tidak menginsyaratkan tentang batasan baligh, hanyak menjelaskan tentang tanda-tanda baligh.

\section{Sejarah Batasan Usia Minimal Kawin Sejak Tahun 1974}

Secara historis, penetapan Undang-Undang (UU) Perkawinan Tahun 1974 diawali pada tahun 1950 mengenai batasan usia minimal perkawinan. Menteri Agama mengeluarkan Surat Keputusan (SK) tertanggal 1 Oktober 1950 Nomor b/2/4299 yang berisi pembentukan suatu kepanitiaan "Penyelidik Peraturan Hukum Perkawinan, Talak dan Rujuk" bagi umat Islam dinahkodai oleh Mohammad Hassan. Para anggota perumus mengusulkan agar dibentuk Rancangan Undang-Undang (RUU) Perkawinan yang diberlakukan untuk seluruh warga negara tanpa membedakan suku, bangsa, golongan, ras, maupun agama. Perumusan tersebut mengusahakan agar unifikasi dan kodifikasi hukum perkawinan dapat segera direalisasikan. ${ }^{17}$

Kemudian menurut Instruksi Direktur Jenderal Bimbingan Masyarakat, oleh panitia tersebut disampaikan Rancangan Undang-Undang (RUU) Perkawinan serta draft pertanyaan umum mengenai RUU tersebut yang ditujukan untuk seluruh organisasi pusat maupun lokal, agar masing-masing bisa memberikan pendapat, gagasan atau pandangan mengenai perumusan Undang-Undang Perkawinan. Selain mengusahakan ke arah unifikasi dan kodifikasi, RUU dimaksudkan untuk memperbaiki keadaan di masyarakat tentang dasar-dasar mengenai perkawinan. Salah satu hal penting mengenai perkawinan dapat dilangsungkan apabila terdapat persetujuan kedua belah pihak, serta batasan usia minimal untuk bisa melangsungkan

\footnotetext{
${ }^{16}$ Abd al-Rahman al-Jaziri. 2003. Al-Fiqh ala Madzahib al-Arba'ah. (Beirut: Dar al-Kutub al-Ilmiyyah).

${ }^{17}$ Soetojo Prawirohamidjodjo. 2012. Pluralisme dalam Perundang-Undangan Perkawinan di Indonesia. (Surabaya: Airlangga University Press). h. 16.
} 
perkawinan bagi perempuan berusia 15 (lima belas) dan laki-laki telah berusia 18 (delapan belas) tahun. ${ }^{18}$

Dalam Putusan Mahkamah Agung Rancangan Undang-Undang (RUU) Perkawinan disampaikan kepada Menteri Agama Republik Indonesia pada bulan April 1954. Pada tahun 1957 Menteri Agama menyampaikan Rancangan Undang-Undang (RUU) tersebut dalam sidang kabinet, namun sampai sekian lama tidak ada penyelesaiannya. Pada akhirnya tahun 1958 anggota Dewan Perwakilan Rakyat (DPR) wanita yang diprakarsai oleh Saudari Sumari yang mengusulkan Rancangan Undang-Undang (RUU) tentang Perkawinan yang pada intinya berisikan mengenai peraturan perkawinan umum bagi seluruh warga negara Indonesia (WNI) tanpa membedakan golongan, kelompok, suku, bangsa, ras maupun agamanya. Adapun isi pokok RUU tersebut adalah sebagai berikut: ${ }^{19}$

a. Setiap warga negara berhak untuk kawin/menikah menurut kepercayaan atau pun agama masing-masing;

b. Monogami adalah dasar dari perkawinan;

c. Perkawinan tidak ada unsur paksaan terhadap kedua belah pihak, artinya atas kemauan calon kedua mempelai;

d. Batasan usia calon pengantin yakni telah berusia 18 (lima belas) tahun bagi calon mempelai laki-laki dan bagi seorang perempuan telah berusia berusia 15 (lima belas).

Setelah beberapa kali pemerintah mengajukan RUU perkawinan (sejak tahun 1952 s.d. tahun 1958) kepada Dewan Perwakilan Rakyat (DPR), selalu berakhir dengan kegagalan. ${ }^{20}$ Sehingga pada tahun 1963 pemerintah didesak agar segera meninjau ulang Rencana UndangUndang (RUU) tentang perkawinan untuk diajukan kepada DPR RI. Harapannya dengan keluarnya Tap MPRS Nomor XXVII/MPRS/1966, MPRS mendesak pemerintah agar segera mengsahkan Undang-Undang Perkawinan. ${ }^{21}$

Menteri Agama, KH. Moh Dahlan kala itu yang mengatasnamakan pemerintah menanggapi atas keluarnya Tap MPRS 22 Mei 1967, kemudian menyampaikan kembali RUU Perkawinan untuk umat Islam kepada DPR-GR (Dewan Perwakilan Rakyat-Gotong Royong). Pada tanggal 7 September 1967, Departemen Kehakiman juga mengajukan lagi RUU

\footnotetext{
${ }^{18}$ Soetojo Prawirohamidjodjo. 2012. Pluralisme dalam Perundang-Undangan Perkawinan di Indonesia. h. 17. ${ }^{19}$ Soetojo Prawirohamidjodjo. 2012. Pluralisme dalam Perundang-Undangan Perkawinan di Indonesia. h. 18.

${ }^{20}$ Taufiqurrahman Syahuri. 2013. Legislasi Hukum Perkawinan di Indonesia: Pro-Kontra Pembentukan Hingga Putusan Mahkamah Konstitusi. (Jakarta: Prenada Media). h. 95.

${ }^{21}$ Ahmad Masfuful Fuad. 2016. "Ketentuan Batas Minimal Usia Kawin: Sejarah, Implikasi Penetapan UndangUndang Perkawinan," Jurnal Petita, 1 (1): h. 34-35.
} 
Perkawinan yang bersifat nasional. Gejolak pun tidak bisa dihindari dan muncul di permukaan mengenai perbedaan latar belakang pandangan, rivalitas politik dan pola pikir di antara kedua departemen masing-masing yang didominasi oleh Partai Politik, sehingga DPR enggan membicarakannya lebih jauh. Sehingga pada akhirnya kedua RUU tersebut dinyatakan dihentikan sampai pada tahun 1971, yakni setelah dibentuknya DPR RI yang baru pasca hasil pemilu tahun $1971 .^{22}$

Tepat pada 31 juli 1973 pemerintah dapat menyiapkan sebuah Rancangan UndangUndang (RUU) Perkawinan yang baru kepada DPR yang terdiri dari 15 bab dan 73 pasal. RUU tersebut memiliki tiga tujuan penting. Pertama, kepastian hukum bagi persoalan-persoalan perkawinan belum terumuskan secara baik, dikarenakan Undang-Undang (UU) tentang Perkawinan sifatnya hanya judge made law; Kedua, perlindungan terhadap hak-hak. Ketiga, mewujudkan perundang-undangan yang sesuai dengan perubahan dan perkembangan zaman. ${ }^{23}$

Setelah proses pembicaraan tingkat ke-1 dan 2 sesuai dengan Peraturan Tata Tertib DPR RI, maka terbentuklah sebuah Panitia Kerja dari gabungan Komisi III dan IX, yang terdiri atas 10 orang anggota tetap dan di samping itu ditunjuk sejumlah 15 orang anggota pengganti yang bertugas menggantikan anggota-anggota tetap bilamana ada yang berhalangan hadir. Panitia tersebut mempunyai status seperti komisi agar mengadakan pembahasan tingkat ke-3 dengan pemerintah. Pembahasan berlangsung sejak 6 sampai dengan 20 Desember 1973, baik intern panitia maupun bersama pemerintah, telah dibahas secara menyeluruh, baik dari segi tujuan, isi, maupun ditinjau dari segi formulasinya serta teknis yuridisnya. ${ }^{24}$

Dalam rapat tersebut, pokok dari pembicaraan telah bersepakat bahwa perkawinan harus sesuai dengan kerelaan, tidak ada paksaan antara calon suami maupun istri. Hal ini dimaksudkan agar terhindar dari kemungkinan kawin paksa. Oleh karenanya, batasan usia minimal agar dapat melangsungkan perkawinan disepakati sekurangnya berusia 21 (dua puluh satu) tahun bagi laki-laki dan berusia 18 (delapan belas) tahun bagi perempuan. Pada akhirnya, para peserta sepakat bahwa perkawinan yang berasaskan persamaan hak dan monogami di dalam pengajuan gugatan cerai baik pada suami maupun istri. ${ }^{25}$

\footnotetext{
${ }^{22}$ Achmad Gunaryo. 2006. Pergumulan Politik dan Hukum Islam: Reposisi Peradilan Agama dari Peradilan "Pupuk Bawang” Menuju Peradilan Sesungguhnya. (Yogyakarta: Pustaka Pelajar). h. 251.

${ }^{23}$ Nafi' Mubarak. 2012. "Sejarah Hukum Perkawinan oleh Wakil-Wakil Fraksilam di Indonesia," Al-Hukuma: The Indonesian Journal of Islamic Law, 12 (2): h. 152.

${ }^{24}$ Soetojo rawirohamidjojo. 2012. Pluralisme dalam Perundang-Undangan Perkawinan di Indonesia. h. 20.

${ }^{25}$ Bonnie Triyana. "Asal-Usul Batas Usia Minimal dalam UU Perkawinan No.1/1974," 2020, https://historia.id/politik/articles/asal-usul-batas-usia-minimal-dalam-uu-perkawinan-no-1-1974-DbN4q, dikases pada 8 Maret 2020.
} 
Setelah lebih dari 30 tahun berjuang merumuskan Undang-Undang (UU) Perkawinan yang disampaikan dalam sidang paripurna DPR pada 22 Desember 1973 agar disahkannya menjadi Undang-Undang. Dalam sidang tersebut, fraksi-fraksi yang hadir di DPR (Fraksi Persatuan Pembangunan, Fraksi ABRI, Demokrasi Indonesia dan Fraksi Karya Pembangunan) dan Menteri Agama yang mewakili pemerintah mengemukakan pendapat masing-masing terkait dengan RUU ini. ${ }^{26}$

Penyusunan RUU di awal pemerintahan orde baru telah mengakibatkan perdebatan khususnya dari kelompok Islam. RUU umum seperti yang sudah dijelaskan di atas juga belum mendapatkan titik temu. Hal ini dapat dipahami bahwa umat Islam merasa dipecundangi oleh sebagian kelompok, sehingga memunculkan reaksi yang juga tidak dapat tertampung. Reaksi dari berbagai kelompok Islam menjadi catatan sejarah bahwa untuk masalah keyakinan atau hukum keluarga, dapat dibuktikan bahwa umat Islam masih sangat rentan untuk diganggu. Demikian kiranya politik pemerintah Hindia Belanda kala itu, masyarakat Indonesia yang secara sangat hati-hati ketika berurusan dengan hukum. ${ }^{27}$

Setelah melalui proses yang panjang dan alot, upaya untuk meyakinkan seluruh warga negara Indonesia mengenai tujuan yang telah disepakati yakni untuk mewujudkan suatu Undang-Undang (UU) tentang Perkawinan yang sejauh mungkin dalam memenuhi aspirasi hukum yang hidup di tengah-tengah masyarakat. Selain itu, agar dapat memberikan pengarahan bagi perkembangan hukum di masa depan. Akhirnya pada 2 Januari 1974, Undang-Undang Nomor 1 Tahun 1974 tentang Perkawinan disahkan di Jakarta oleh Presiden Soeharto. ${ }^{28}$

Pada waktu bersamaan dengan Lembaran Negara 1974 Nomor 1 Tambahan Lembaran Negara Nomor 3019 diundangkan Undang-Undang Republik Indonesia Nomor 1 Tahun 1974 Tentang Perkawinan oleh Menteri/Sekretaris Negara Sudharmono. Undang-undang tersebut dalam bentuknya yang definitif terdiri atas 67 pasal dalam XIV bab yang semua dalam rancangan undang-undangnya sendiri terdiri dari 72 pasal dalam XV bab. ${ }^{29}$

Isi dari Undang-Undang (UU) tentang Perkawinan tersebut yang tertuang di dlaam Bab I mengandung 5 pasal tentang dasar-dasar perkawinan. Kemudian undang-undang membicarakan secara berturut-turut mengenai syarat-syarat perkawinan yang tertuang dalam pasal 6-12, pencegahan perkawinan (Bab III pasal 13-21) dan batalnya perkawinan (Bab IV

\footnotetext{
${ }^{26}$ Ahmad Tholabi Kharlie. 2013. Hukum Keluarga Indonesia. (Jakarta: Sinar Grafika). h.166.

${ }^{27}$ Ahmad Tholabi Kharlie. 2013. Hukum Keluarga Indonesia. h. 167.

28“UU 1 Tahun 1974 Tentang Perkawinan," 2020. https://www.jogloabang.com/pustaka/uu-1-1974-perkawinan, diakses pada 17 Februari 2020.

${ }^{29}$ Soetojo Prawirohamidjojo. 2012. Pluralisme dalam Perundang-Undangan Perkawinan di Indonesia. h. 21.
} 
pasal 22-28). Sedangkan pada Bab V hanya terdiri atas satu pasal saja yang mengatur mengenai perjanjian perkawinan; dan Bab VI pasal 30-34 mengatur tentang hak dan kewajiban suami isteri.

Tiga pasal berturut-turut yang kesemuanya merupakan Bab VIII (pasal 38-41) memberikan beberapa pengaturan tentang putusnya perkawinan serta akibat-akibatnya; Bab IX berisikan pengaturan tentang kedudukan anak-anak; sedangkan Bab X (psaal 45-49) berisikan hak-hak dan kewajiban orang tua dan anak diatur di dalam Bab X. Beberapa peraturan tentang perkawinan terdapat dalam bab XI (pasal 50-53). Bab XII mengandung ketentuan-ketentuan yang berlainan. Yang terpenting ialah pengaturan tentang perkawinan campuran (pasal 56) dan lebih-lebih pasal 63 menentukan bahwa seluruh wilayah Indonesia ada dua macam pengadilan, yaitu pengadilan agama bagi mereka yang beragama Islam dan Pengadilan umum bagi yang lain-lainnya. Kedua bab yang terakhir (XIII dan XIV), masing-masing berisikan dua ketentuan, yakni peralihan dan penutup..$^{30}$

Undang-Undang (UU) Perkawinan Nomor 1 Tahun 1974, batas usia minimal perkawinan terdapat pada pasal 7 (1): "Perkawinan hanya diizinkan jika pihak pria sudah mencapai umur 19 (sembilan belas) tahun dan pihak perempuan sudah mencapai umur 16 (enam belas) tahun." Tujuan dari adanya pasal 7 ayat 1 mengenai ketentuan pembatasan usia calon mempelai yakni untuk mencegah terjadinya perkawinan anak di bawah umur. Selain itu, tujuannya adalah agar calon suami istri yang hendak melangsungkan perkawinan sudah matang (dewasa) jiwa dan raganya, sehingga bisa membangun rumah tangga dengan sebaik-baiknya.

Ketentuan pasal tersebut juga dimaksudkan untuk menjaga kesehatan suami maupun istri serta mengendalikan angka kelahiran. Oleh karena itu, dalam penjelasan umum angka 4 sub d Undang-Undang Nomor 1 Tahun 1974 disebutkan:

"Perkawinan mempunyai hubungan dengan masalah kependudukan. Ternyatalah bahwa batas umur yang lebih rendah bagi seorang wanita untuk kawin, mengakibatkan laju kelahiran yang lebih tinggi. Berhubung dengan itu, maka undang-undang ini menentukan batas umur untuk kawin baik pria maupun bagi wanita, ialah 19 (sembilan belas) tahun bagi pria dan 16 (enam belas) tahun bagi wanita". ${ }^{11}$

Penentuan batasan usia perkawinan dilandasi atas pertimbangan dan dasar untuk mencapai kemaslahatan keluarga dalam membangun rumah tangga. Sesuai dengan prinsip Undang-Undang tentang Perkawinan Indonesia, bahwa calon mempelai laki-laki maupun perempuan yang telah matang (dewasa) baik secara jiwa maupun raganya dianjurkan untuk

\footnotetext{
${ }^{30}$ Soetojo Prawirohamidjojo. 2012. Pluralisme dalam Perundang-Undangan Perkawinan di Indonesia. h. 21.

${ }^{31}$ Riduan Syahrani. 2013. Seluk Beluk dan Asas-Asas Hukum Perdata. (Bandung: Alumni). h. 67.
} 
segera menunaikan perkawinan. Selain itu, pencegahan mengenai adanya perkawinan di bawah umur tetap harus dilakukan secara masif. ${ }^{32}$

\section{Lahirnya Undang-Undang Nomor 1 Tahun 2019}

Lebih dari 45 tahun dihitung setelah disahkannya undang-undang perkawinan, yakni Undang-Undang (UU) Nomor 1 Tahun 1974 tentang Perkawinan sejak diberlakukan, permasalahan mengenai batasan usia minimal perkawinan tidak kunjung reda. Kemudian Ketua Dewan Pengurus Yayasan Kesehatan Perempuan bernama Zumrotin K. Susilo pada bulan Maret 2014 mengajukan permohonan uji materi (judicial review) Pasal 7 ayat (1) UndangUndang (UU) Perkawinan, khususnya pasal tentang usia perkawinan bagi perempuan yang dinilai berdampak kompleks terhadap perempuan di Indonesia. Beliau berpendapat bahwa kuasa hukum yang telah menyelesaikan draft uji materi dan diajukan pada bulan Maret 2014. Draft uji materi tersebut berisi mengenai fakta-fakta mengenai dampak perkawinan usia dini. Dampak tersebut mulai dari sisi psikologis, kesehatan, sosial, dan ekonomi. Dengan penuh harap hakim Mahkamah Konstitusi (MK) agar merevisi usia perkawinan perempuan dari 16 tahun menjadi di atas 18 tahun. $^{33}$

Pada tahun 2016, koalisi 18+ melakukan riset mengenai dispensasi perkawinan di Pengadilan Agama pada tiga daerah di Indonesia yang hasilnya adalah angka perkawinan usia dini terbilang cukup tinggi, yakni di Kabupaten Tuban, Kabupaten Mamuju dan Kabupaten Bogor. Putusan dispensasi perkawinan usia dini di Pengadilan Agama pada tiga wilayah tersebut diambil antara tahun 2013 hingga tahun 2015. Kesimulannya, bahwa 377 permohonan dispensasi yang diajukan, sekitar 97,6\% permohonan dikabulkan. Oleh para hakim sangat sedikit, yakni sebanyak 2,66\%. Hal itu pun terjadi hanya dikarenakan persoalan administrasi dan prosedural, misalnya subjek dispensasi tidak hadir dan hanya satu putusan yang ditolak hakim dikarenakan pertimbangan pelanggaran hak anak. ${ }^{34}$

Mahkamah Konstitusi (MK) mengabulkan sebagian permohonan pemohon, sehingga pada Desember 2018 Mahkamah Konstitusi menyatakan bahwa "usia 16 (enam belas) tahun" dalam Pasal 7 ayat (1) adalah bertentangan dengan UUD 1945 dan tidak memiliki kekuatan

\footnotetext{
${ }^{32}$ Nur Wahid. 2019. "Historisitas dan Tujuan Aturan Umur Minimal Perkawinan dalam Perundang-Undangan Keluarga Islam di Indonesia,” Journal Volksgeist, 2 (2): h. 107.

${ }^{33}$ Dina Manafe. 2020. "Yayasan Kesehatan Perempuan Ajukan Uji Materil UU Perkawinan Ke MK," diakses 10 pada Maret 2020.

34، Anak Membutuhkan Perlindungan Hukum dari Perkawinan Anak Bukan Ancaman Pidana," 2020,https://icjr.or.id/anak-membutuhkan-perlindungan-hukum-dari-perkawinan-anak-bukan-ancamanpidana/print, diakses 6 pada April 2020.
} 
hukum mengikat. Amar putusan Mahkamah Konstitusi (MK) menujuk kepada pembentuk undang-undang dalam jangka waktu paling lama 3 (tiga) tahun untuk melakukan perubahan terhadap Undang-Undang Nomor 1 Tahun 1974 tentang Perkawinan (Lembaran Negara Republik Indonesia Tahun 1974 Nomor 1, Tambahan lembaran Negara Republik Indonesia Nomor 3019), mengenai batasan minimal usia perkawinan bagi perempuan maupun laki-laki. ${ }^{35}$

Pada akhirnya setelah melalui proses yang rumit dan cukup panjang, bulan September 2019 pada Sidang Paripurna, DPR sepakat dan menyetujui perubahan terbatas Undang-Undang (UU) Nomor 1 Tahun 1974 tentang Perkawinan. Pembaharuan Undang-Undang Nomor 1 Tahun 1974 Pasal 7 pantas untuk dilakukan, di antaranya adalah menaikkan batas usia minimal perkawinan yang sama, baik bagi perempuan maupun laki-laki menjadi usia 19 (sembilan belas) tahun. Perubahan pasal 7 ini juga memberikan aturan pengecualian jika perkawinan di bawah umur harus dilakukan maka pengecualian harus dilengkapi dengan alasan yang sangat mendesak dan bukti-bukti yang kuat. ${ }^{36}$

Mengenai latar belakang pertimbangan dalam perubahan atas Undang-Undang (UU) Nomor 1 Tahun 1974 adalah sebagai berikut:

a. Perkawinan/Pernikahan pada anak di bawah umur (usia dini) memunculkan dampak negatif bagi perkembangan dan pertumbuhan anak, serta dikhawatirkan hak-hal anak tida terpenuhi, seperti hak atas perlindungan dari kekerasan, pendidikan, sipil, hingga sosial;

b. Setiap warga negara memiliki hak dalam membentuk keluarga dan melanjutkan keturunan melalui perkawinan yang sah, menjamin keamanan dan perlindungan kelangsungan hidup, kekerasan dan diskriminasi sebagaimana yang diamanatkan dalam UUD NKRI 1945;

c. Sesuai putusan Mahkamah Konstitusi (MK) Republik Indonesia dengan Nomor 22/PUUXV/2017 perlu dilaksanakannya perubahan atas ketentuan Pasal 7 Undang-Undang (UU) Nomor 1 Tahun 1974;

d. Atas pertimbangan sebagaimana dimaksud dalam huruf a, huruf b, dan huruf c, perlu membentuk Undang-Undang (UU) tentang Perubahan atas Undang-Undang Nomor 1 Tahun 1974 tentang Perkawinan; ${ }^{37}$

\footnotetext{
${ }^{35}$ Dewi Komalasari. 2020. "Perjuangan Mengakhiri Perkawinan Anak di Indonesia Membuahkan Hasil," diakses 6 pada April 2020.

${ }^{36}$ Dewi Komalasari. 2020. "Perjuangan Mengakhiri Perkawinan Anak di Indonesia Membuahkan Hasil," diakses 6 April pada 2020.

37،UU 1 Tahun 1974 Tentang Perkawinan. https://www.jogloabang.com/pustaka/uu-16-2019-perubahan-uu-11974-perkawinan, diakses pada 25 Februari 2020.
} 
Adapun aturan mengenai usia perkawinan adalah sebagai berikut: Pertama, idealnya untuk melangsungkan perkawinan yakni telah berusia minimal 21 tahun. Kedua, batasan usia minimal kawin berbeda antara perempuan dengan laki-laki, yakni 16 (enam belas) tahun bagi perempuan dan 19 (sembilan belas) tahun bagi laki-laki. Undang-Undang mengenai perkawinan masih melanggengkan praktik perkawinan anak usia dini, khususnya bagi anak perempuan melalui pengaturan batas usia perkawinan 16 (enam belas) tahun dan dimungkinkan adanya pemberian keringanan perkawinan usia dini telah diatur dalam undang-undang tersebut.

Namun dalam kenyataannya, angka perkawinan di usia dini di Indonesia masih tergolong tinggi, yakni sekitar 375 anak perempuan menikah tiap hair, dikarenakan 1 di antara 9 anak perempuan di bawah usia 18 tahun. ${ }^{38}$ Selain itu, dampak perkawinan pada usia dini sangat beragam di antaranya, anak-anak akan kehilangan hak-hak untuk tumbuh dan berkembang, hak atas pendidikan dan kerentanan mengalami kekerasan seksual. Sedangkan dampak lainnya, kehamilan usia dini juga turut menyumbang tingginya angka kematian ibu yang melahirkan.

Selain itu, dengan menaikkan batasan usia minimal yang lebih bagi perempuann akan mengakibatkan laju kelahiran anak yang lebih rendah dan mampu menekan resiko kematian bagi ibu dan anak. Jika bisa terpenuhi, maka hak anak bisa bertumbuh dan berkembang secara optimal sehinga dapat terpenuhi akses pendidikan, kesehatan, dan sosial.

Setelah mengalami banyak upaya pembaharuan, Undang-Undang (UU) Nomor 16 Tahun 2019 tentang perubahan Undang-Undang (UU) Nomor 1 Tahun 1974 pada akhirnya disahkannya pada tanggal 14 Oktober 2019 oleh Presiden Republik Indosia Ir. Joko Widodo di Jakarta. Kemudian Undang-Undang tersebut mulai diberlakukan setelah disahkan oleh Plt. Menkumham Tjahjo Kumolo pada tanggal 15 Oktober 2019.

\section{Pro dan Kontra Batasan Usia Minimal Kawin UU Nomor 16 Tahun 2019}

Usia menurut hukum positif telah ditetapkan dalam Undang-Undang Nomor 16 Tahun 2020, baik bagi laki-laki maupun perempuan yang hendak menikah maka harus berusia 19 (sembilan belas) tahun. Dengan harapan bisa memberikan manfaat yang lebih serta kedewasaan. Namun pada kenyataannya, sebagian besar masyarakat jarang sekali mematuhi hukum yang berlaku, padahal dengan ditetapkannya hukum tersebut demi kemaslahatan bagi banyak orang. Akibatnya perkawinan usia dini masih sering terjadi.

\footnotetext{
${ }^{38}$ Lihat data yang dilansir oleh UNICEF pada tahun 2018, yang bersumber pada data Susenas 2016 https://www.unicef.org/indonesia/Child_Marriage_SDG_Factsheet_english.pdf, diakses 30 Mei 2019.
} 
Permasalahan yang muncul dari batas usia perkawinan yang memiliki perbedaan antara laki-laki yang berusia 19 (sembilan belas) tahun dan perempuan 16 (enam belas) tahun batas usia ini dianggap sebagai permasalahan dalam perspektif hak anak usia 19 (sembilan belas) tahun telah dikategorikan dewasa, tetapi usia bagi perempuan 16 (enam belas) tahun yang masuk dalam kategori usia anak hal ini merupakan bentuk diskriminasi berdasarkan jenis kelamin yang bertentanga dengan peraturan perundang-perundangan di Indonesia sebagaimana dijamin oleh pasal 3 Undang-Undang HAM dan pasal 1 konvensi hak perempuan. ${ }^{39}$

Menurut Jaenal Syarifudin, selaku penghulu KUA Tegalrejo, beliau mendukung dengan adanya undang-undang baru mengenai perubahan batas usia menikah tersebut. Dikarenakan memang sebelumnya yang usia 16 (enam belas) tahun menurut beliau masih terlalu muda dan 19 (sembilan belas) tahun usulan dari berbagai kalangan juga termasuk belum matang. Namun usia 19 (sembilan belas) lebih lumayan dari pada usia 16 tahun walaupun pada kenyataannya di lapangan masih menjadi polemik dan banyak permasalahan di KUA, hal ini dikarenakan menurut beliau akan semakin banyak yang mengajukan dispensasi di pengadilan.

Mengenai persoalan dinaikkannya batasan minimal usia perkawinan itu memicu hamil pra nikah, menurutnya berapa pun bisa saja, baik itu usia 21 (dua puluh satu) tahun atau bahkan 16 (enam belas) tahun, sama saja. Hal itu didasarkan oleh perilaku seseorang. Jadi, hal itu bukan hal yang bisa disetarakan. Mungkin di lapangan bisa saja muncul masalah hamil pra nikah, tetapi bukan alasan untuk menurunkan batasan usia minimal melangsungkan perkawinan kembali dan usia 19 (sembilan belas) tahun itu sudah cukup bagus dan cukup matang (dewasa) secara psikologis maupun fisik.

Sementara Menurut Kholis Asy'ari selaku Penghulu di KUA Kecamatan Jetis, dengan dinaikannnya batasan minimal usia perkawinan pada perempuan menjadi sama dengan lakilaki yakni usia 19 (Sembilan belas) tahun, beliau sangat mendukung. Selaku Aparatur Sipil Negara (ASN) tinggal manut dengan apa yang sudah ditetapkan oleh pemerintah, terutama atas disahkannya Undang-Undang (UU) Nomor 16 Tahun 2019 tentang perkawinan mengenai batasan minimal usia melasungkan perkawinan. Terkait pasal ini, beliau meyakini bahwa hal ini dapat menjadi solusi untuk meminimalisir angka perkawinan di usia dini walaupun hanya batas usianya yang berubah, dari usia 16 (enam belas) menjadi usia 19 (sembilan belas) tahun bagi perempuan.

\footnotetext{
${ }^{39}$ Koalisi Perempuan Indonesia untuk Keadilan dan Demokrasi Pusat Kajian Hukum Gender dan Masyarakat," Naskah Akademik RUU Perubahan UU No. 1 Tahun 1974 tentang Perkawinan," Fakultas Hukum UGM. t.t. h. 18.
} 
Secara psikologis, bahwa kematangan seseorang berbeda-beda. Jika memang sudah diputuskan menjadi 19 (Sembilan belas) tahun, menurut beliau sudah cukup dewasa. Artinya menurut beliau dipungkiri bahwa usia tersebut masih terbilang dini, meskipun telah ditetapkan pada undang-undang dan tentu sudah melalui tahapan-tahapan atau pertimbanganpertimbangan yang matang dari berbagai pihak serta pemangku kebijakan.

Adapun menurut Gufron Su'udi selaku kepala KUA Mergangsan, dari sekian tuntutan revisi undang-undang tentang batasan usia minimL perkawinan, setidaknya ada tiga hal penting. Pertama, dihapuskannya isu diskriminatif; Kedua, pencegahan perkawinan usia dini; dan Ketiga, sebagai upaya mendewasakan usia perkawinan. Namun menurutnya, revisi yang telah dilakukan DPR tersebut baru bisa mengakomodir tuntutan dihilangkannya isu diskriminatif, yakni disetarakan bagi laki-laki maupun perempuan. Perubahan undang-undang belum tentu bisa menjawab ketiga tuntutan tersebut, hal ini dikarenakan ketentuan yang terdapat dalam pasal 7 ayat (2) Undang-Undang (UU) Perkawinan disebutkan bahwa ketika terjadi penyimpangan terhadap ayat (1) tersebut, maka masih ada peluang untuk memohon dispenasi (keringanan) nikah ke pengadilan. Artinya, meskipun batas minimal usia perkawinan telah ditetapkan usia 19 (sembilan belas) tahun, tetapi ketika pengadilan memberikan dispensasi kepada calon mempelai yang masih di bawah 19 (sembilan belas) tahun, maka perkawinan anak di usia dini pun masih tetap bisa dilaksanakan.

Menurut pendapat Nanang Kosim, PPN KUA Pakualaman, beliau berpendapat bahwa seseorang yang telah berusia 21 (dua puluh satu) tahun bagi laki-laki, san 19 tahun bagi perempun, menurut beliau itu sudah cukup dewasa. Artinya laki-laki yang baru berusia 19 (sembilan belas) tahun menurut beliau masih belum siap dari segi ekonomi, emosional dan belum juga siap untuk mengurus rumah tangganya. Dari pemaparan beliau ini, beliau tidak mendukung perubahan undang-undang baru ini dan lebih mendukung yang usulan dari BKKBN yaitu usia pernikahan ideal 21-25 tahun. Menurut beliau usia tersebut lebih menjamin kematangan secara psikologis bagi kedua mempelai yang akan melasungkan perkawinan dan dianggap sudah siap untuk membangun rumah tangga.

Bahwasannya dalam kehidupan rumah tangga membutuhkan kematangan emosinal dan juga pemikiran untuk menghadapi dan mengendalikan hakikat perkawinan dan peran orang tua yang akan disandang. Selain itu, kematangan emosi merupakan salah satu aspek penting untuk menjaga kelangsungan perkawinan. Perbedaan kematangan emosi yang signifikan pada pria 
dan wanita yang menikah terlalu muda, di mana ditemukan bahwa pria memiliki emosi lebih tinggi dibandingkan dengan wanita. ${ }^{40}$

Mengenai tujuan untuk meminimalisir hamil pra nikah, menurut beliau undang-undang tersebut tidak dapat menjadi solusi utama. Dikarenakan yang mengajukan permohonan dispensasi kawin yakni dengan kasus pihak perempuan telah hamil terlebih dahulu sebelum melangsungkan pernikahan. Di samping itu, justeru dengan alasan perempuan yang telah hamil terlebih dahulu sering dikabulkan oleh hakim dengan dalih untuk menyelamatkan status anak yang dikandungnya. Menurut beliau hal ini tergantung kultur di masyarakat, kalau di Yogyakarta misalanya, perkawinan anak usia dini kebanyakan telah hamil pra nikah, sedangkan di daerah istri beliau tepatnya di daerah Jawa Barat anak yang baru lulus SMP atau yang khatam al-Qur'an sudah langsung dinikahkan. Seperti halnya di daerah pelosok desa, perkawinan usia dini merupakan hal yang sudah lumrah dan dianggap biasa.

Pada dasarnya, secara umum kedewasaan dijadikan sebagai asas penting oleh pembuat kebijakan dalam menetapkan undang-undang tentang perkawinan sebagai hukum positif yang harus dipatuhi oleh semua warga tanpa terkecuali. Selain itu, untuk merevisi dalam menentukan batasan usia yang akan melangsungkan perkawinan pun membutuhkan waktu rentang yang cukup panjang yakni sekitar 45 tahun. Hal ini dilakukan atas berbagai pertimbangan, salah satunya bahwa perkawinan pada usia dini bisa mengakibatkan efek negatif bagi pertumbuhan sekaligus perkembangan dan hak anak. ${ }^{41}$

Untuk meminimalisir angka kasus pernikahan usia dini, undang-undang baru yang telah disahkan tersebut belum sepenuhnya menjadi solusi dikarenakan kasus-kasus hamil pra nikah cukup tinggi, sehingga pengajuan dispensasi menikah juga tidak dapat dihindarkan. Oleh karena itu, faktor kedewasaan dan kematangan secara emosional menjadi amat penting dan serius, dikarenakan dapat memberikan dampak yang nyata dalam membangun rumah tangga.

\section{KESIMPULAN}

Dinamika pembaharuan hukum keluarga Islam di Indonesia dimulai sejak tahun 1960, yakni sejak disahkannya Undang-Undang (UU) Perkawinan Nomor 1 tahun 1974, yang kemudian setelah kurang lebih 45 tahun undang-undang tersebut kemudian direvisi, sehingga

\footnotetext{
${ }^{40}$ Walter N. Stinnet and Kaye. 1984. Relationship in Marigae and the Family. New York: MacMillan Publishing.co.

${ }^{41}$ Pitrotussaadah dan Mimin Mintarsih. 2020. "Batas Usia Minimal Perkawinan Menurut Perspektif Hukum Positif di Indonesia dan Hukum Islam,” Jurnal Muttaqien 1 (1): h. 85.
} 
lahirlah Undang-Undang (UU) Nomor 16 Tahun 2019. Tujuan pembaharuan hukum keluarga Islam yang dimaksudkan dapat mengangkat status dan derajat perempuan, prinsip keadilan, unifikasi hukum, serta pengkodifikasian hukum yang sesuai dengan konteks perkembangan zaman.

Terlepas dari pro dan kontra atas lahir dan disahkannya undang-undang tersebut belum sepenuhnya menjawab tantangan zaman. Hal ini sesuai dengan pandangan Pegawai Pencatat Nikah (PPN), bahwa usia belum tentu menjamin kematangan atau kedewasaan dan emosional seseorang. Dengan disahkannya undang-undang baru tersebut diharapkan bisa menekan dan meminimalisir angka perkawinan anak usia dini. Selain itu, unifikasi hukum tentang perkawinan juga penting dilakukan sebagai upaya penyatuan hukum yang beraneka ragam di setiap daerah di Indonesia, sehingga antara hukum agama (Islam), hukum adat dan hukum negara bisa diberlakukan sebagai suatu hukum nasional yang berkeadilan.

\section{DAFTAR PUSTAKA}

Al-Damasqy, Al-Imam Abi Fada' al-Hafidz Ibnu Katsir. 2004. Tafsir Ibnu Katsir. Beirut: Dar al-Kutub al-'Ilmiyyah.

Al-Jaziri, Abd al-Rahman. 2003. Kitab Al-Figh Ala Madzahib Al-Arba'ah. Bayrut: Dar alKutub al-Ilmiyyah.

Al-Mufarraj, Sulaiman. 2003. Bekal Pernikahan: Hukum, Tradisi, Hikmah, Kisah, Sya'ir, Wasiat, Kata Mutiara. Jakarta: Qisthi Press.

Al-Shabuny, Muhammad Ali. 1999. Tafsir Ayat al-Ahkam Min Al-Qur'an. Beirut: Dar al-Kutub al-'Ilmiyyah.

"Anak Membutuhkan Perlindungan Hukum dari Perkawinan Anak Bukan Ancaman Pidana," 2020. (https://icjr.or.id/anak-membutuhkan-perlindungan-hukum-dari-perkawinan-anakbukan-ancaman-pidana/print).

Asrori, Achmad. 2015. "Batas Usia Perkawinan Menurut Fukaha dan Penerapannya dalam Undang-Undang Perkawinan di Dunia Islam.” Jurnal Al-Adalah, 12 (4).

Cammark, Mark E. 1993. "Hukum Islam Dan Politik Orde Baru." In Perkembangan Mutakhir Hukum Islam di Asia Tenggara: Studi Kasus Hukum Keluarga Dan Pengkodifikasiannya. Bandung: Mizan.

Djamilah dan Reni Kartikawati. 2014. "Dampak Perkawinan Anak di Indonesia” Jurnal Studi Pemuda, 3 (1).

Fuad, Ahmad Masfuful. 2016. "Ketentuan Batas Minimal Usia Kawin: Sejarah, Implikasi Penetapan Undang-Undang Perkawinan.” Jurnal Petita, 1 (1).

Gunaryo, Achmad. 2006. Pergumulan Politik dan Hukum Islam: Reposisi Peradilan Agama dari Peradilan "Pupuk Bawang” Menuju Peradilan Sesungguhnya. Yogyakarta: Pustaka Pelajar.

Hakim, Rahmat. 2000. Hukum Perkawinan Islam. Bandung: Pustaka Setia.

Hazarin. 1986. Tinjauan Mengenai Undang-Undang Perkawinan Nomor 1/1974. Jakarta: Tintamas Indonesia.

Holilurrohman. 2016. "Batas Usia Ideal Pernikahan Perspektif Maqasid Syariah.” Journal of Islamic Studies and Humanities, 1 (1). 
Ija Suntana. 2014. Politik Hukum Islam. Bandung: Pustaka Setia.

Karim, Helmi. 1996. Kedewasaan untuk Menikah, Alih Bahasa Chuzaimah T. Yanggo dan Hafiz Anshary dari "Problematika Hukum Islam Kontemporer." Jakarta: Pustaka Firdaus.

Kautsar, Maulana. 2019. "UU Perkawinan Diteken, Usia Minimal Menikah 19 Tahun,". (https://www.dream.co.id/news/uu-perkawinan-diteken-batas-minimal-menikah-19tahun-191024i.html).

Kharlie, Ahmad Tholabi. 2013. Hukum Keluarga Indonesia. Jakarta: Sinar Grafika.

Komalasari, Dewi. 2020. "Perjuangan Mengakhiri Perkawinan Anak Di Indonesia Membuahkan Hasil,” (https://www.jurnalperempuan.org/warta-feminis/perjuanganmengakhiri-perkawinan-anak-di-indonessia-membuahkan-hasil), diakses 6 April 2020.

Latief, M. Nur Hasan. 2016. "Pembaharuan Hukum Keluarga Serta Dampaknya Terhadap Pembatasan Usia Minimal Kawin Dan Peningkatan Status Wanita." Hukum Novelty, 7 (2).

Lukito, Ratno. 2008. Hukum Sakral dan Sekuler: Studi Tentang Konflik dan Resolusi Konflik dalam Sistem Hukum di Indonesia. Jakarta: Alvabeta.

Manafe, Dina. "Yayasan Kesehatan Perempuan Ajukan Uji Materil UU Perkawinan Ke MK.

Mubarak, Nafi'. 2012 "Sejarah Hukum Perkawinan Oleh Wakil-Wakil Fraksilam Di Indonesia." Al-Hukuma: The Indonesian Journal of Islamic Law, 12 (2).

Mustofa. 2009. Perbandingan Hukum Perkawinan di Dunia Islam. Bandung: Pustaka al-fikriis.

Nazaruddin, Nirwan. 2020 "Sakinah, Mawaddah, Wa Rahmah sebagai Tujuan Pernikahan: Tinjauan Dalil dan Perbandingannya dengan Tujuan Lainnya Berdasarkan Hadits Shahih." Jurnal Asy-Syukriyyah 21 (2).

Pitrotussaadah, and Mimin Mintarsih. 2020. "Batas Usia Minimal Perkawinan Menurut Perspektif Hukum Positif di Indonesia dan Hukum Islam.” Jurnal Muttaqien, 1 (1).

Prawirohamidjojo, Soetojo. 2012. Pluralisme dalam Perundang-Undangan Perkawinan di Indonesia. Surabaya: Airlangga University Press.

Sahbani, Agus. 2014. "Batas Usia Pernikahan Digugat". (https://m.hukumonline.com/berita/baca/lt533d336b345e4/batas-usia-pernikahandigugat, diakses 1 Februari 2020.

Stinnet, Walter N. and Kaye. 1984. Relationship in Marigae and the Family. New York: MacMillan Publishing.co

Suhendra, Ahmad. 2020. "Reproduksi Kekuasaan Melalui Teks Keagamaan dalam Reproduksi Perempuan." Journal of Gender and Social Inclusion in Muslim Societies, 1 (1).

Suntana, Ija. 2014. Politik Hukum Islam. Bandung: Pustaka Setia.

Syahrani, Riduan. 2013. Seluk Beluk dan Asas-Asas Hukum Perdata. Bandung: Alumni.

Syahuri, Taufiqurrahman. 2013. Legislasi Hukum Perkawinan di Indonesia: Pro-Kontra Pembentukan Hingga Putusan Mahkamah Konstitusi. Jakarta: Prenada Media.

Triyana, Bonnie. “Asal-Usul Batas Usia Minimal dalam UU Perkawinan No.1/1974,” 2020. (https://historia.id/politik/articles/asal-usul-batas-usia-minimal-dalam-uu-perkawinanno-1-1974-DbN4q).

"UU 1 Tahun 1974 Tentang Perkawinan," n.d. (https://www.jogloabang.com/pustaka/uu-11974-perkawinan), diakses 25 Ferbuari 2020.

Wahid, Nur. 2019. "Historisitas dan Tujuan Aturan Umur Minimal Perkawinan dalam Perundang-Undangan Keluarga Islam di Indonesia.” Jurnal Volksgeist, 2 (2). 